\title{
REVIEW DESAIN INTERFACE APLIKASI SOPPPOS MENGGUNAKAN EVALUASI HEURISTIK
}

\author{
Peti Savitri \\ Program Studi Teknik Informatika \\ Sekolah Tinggi Sains dan Teknologi Indonesia \\ Email: petisavitri@gmail.com \\ Muhammad Ispani \\ Program Studi Teknik Informatika \\ Sekolah Tinggi Sains dan Teknologi Indonesia (ST. INTEN) \\ Email: muhammad_ispani@yahoo.com
}

\begin{abstract}
ABSTRAK
Tujuan dari artikel ini adalah melakukan sebuah review terhadap desain antar muka (interface) pada aplikasi yang bernama System Online Payment Point PT Pos Indonesia atau disingkat SOPPPOS. Review menggunakan evaluasi interaksi manusia komputer yang bernama evaluasi heuristik yang diperkenalkan oleh Molich dan Nielsen. Berdasarkan hasil evaluasi menyatakan bahwa secara umum desain interface dan kemudahan pengguna (usability) dari aplikasi SOPPPOS cukup baik, namun masih ada beberapa hal yang perlu diperbaiki terutama dalam karakteristik kemudahan penggunaan.
\end{abstract}

Kata kunci: review, interface, aplikasi SOPPPOS, evaluasi, heuristik.

\begin{abstract}
The purpose of this article is to conduct a review of the design of the interface on an application called System Online Payment Point PT Pos Indonesia or abbreviated SOPPPOS. Review use human computer interaction evaluation called heuristic evaluation introduced by Molich and Nielsen. Based on the evaluation stated that the overall design and ease of user interface (usability) of the application SOPPPOS pretty good, but there are still some things that need to be improved, especially in the characteristics of ease of use.
\end{abstract}

Keywords: review, interface, SOPPPOS aplication, evaluation, heuristic.

\section{PENDAHULUAN}

PT Pos Indonesia merupakan salah satu perusahaan yang menangani jasa layanan kiriman melalui pos, baik surat, paket maupun logistik. Selain itu untuk memperkuat bisnis dasar yang akhir-akhir ini tergerus dengan kemajuan teknologi informasi seperti perkembangan layanan instan messager yang sangat mempengaruhi kinerja korporasi, sehingga menuntut perusahaan untuk bisa menciptakan produk layanan lainnya.

Dengan memanfaatkan kemajuan teknologi PT Pos Indonesia dan memanfaatkan peluang dengan memiliki jaringan yang luas di seluruh pelosok Indonesia, perusahaan mengembangkan bisnis Payment Point (SOPPPOS - System Online Payment Point) dengan membangun berbagai fasilitas infrastruktur dan arsitektur teknologi. Salah satunya mengembangkan Interface / antarmuka aplikasi SOPPPOS yang saat ini telah mengembangkan SOPPPOS versi 4.0.

Aplikasi SOPPPOS digunakan secara luas, selain di lingkungan PT Pos Indonesia aplikasi ini juga digunakan oleh agen-agen resmi PT Pos Indonesia. Sehingga aplikasi ini dituntut untuk bisa berinteraksi dengan para penggunanya. Untuk mengetahui skalabilitas terhadap kemudahan / usabiliy pengguna yang akan berdampak pada peningkatan layanan mutu terhadap pelanggan, dilakukanlah review dengan memanfaatkan suatu teknik evaluasi dalam interaksi manusia komputer yang bernama evaluasi heuristik.

Hal yang ingin ditinjau dalam penulisan artikel ini adalah bagaimana melakukan evaluasi desain interface terhadap aplikasi SOPPPOS menggunakan evaluasi heuristik. Hasil penelitian dapat dijadikan sebagai rujukan bagi tim pengembang aplikasi yang masih berada dalam naungan PT Pos Indonesia 
dalam melakukan perbaikan-perbaikan sistem serta memberikan gambaran dalam menetapkan pedomanpedoman pengembangan desain interface kedepannya.

Evaluasi desain interface merupakan bagian dari materi desain interaksi (interaction design) dalam Interaksi Manusia Komputer (IMK) atau Human Computer Interaction (HCI). Sedangkan desain interaksi itu sendiri didefinisikan sebagai perancangan produk-produk interaktif untuk mendukung orangorang dalam kehidupan dan pekerjaannya setiap hari [1]. Don Norman (1988) dalam The Design of Everyday Things menulis bahwa terdapat beberapa prinsip desain [1], yaitu:

a) Visibility, User dimungkinkan akan semakin dapat mengetahui apa yang akan dikerjakan selanjutnya jika fungsi-fungsi semakin visible.

b) Feedback, Berkaitan dengan visibility,yang berarti pengiriman kembali informasi mengenai aksi yang telah dilakukan dan apa yang telah diselesaikan termasuk suara, highlight, dan animasi, sehingga orang dapat melanjutkan aktivitasnya.

c) Constraints, Merupakan pembatasan terhadap aksi-aksi penting yang dapat dilakukan, sehingga dapat membantu untuk mencegah user dari memilih pilihan yang salah

d) Mapping, Mengarah kepada bagaimana suatu disain dibuat lebih masuk akal, hal ini dikarena hampir semua artifact memerlukan jenis mapping yang sama antara kontrol dan efeknya. Mapping yang baik misalnya yang terdapat pada tanda panah ke atas (sebagai control) yang memiliki efek pergerakan ke atas kursor.

e) Consistency, Desain interface memiliki operasi-operasi yang serupa dan menggunakan elemenelemen yang serupa untuk tugas-tugas yang serupa.

f) Affordances, Merupakans istilah yang digunakan untuk mengarahkan sebuah atribut dari suatu objek yang menyediakan orang untuk tahu bagaimana menggunakannya.

Evaluasi sendiri adalah proses penentuan usability dan acceptability dari produk atau desain yang terukur di dalam sebuah varietas kriteria termasuk sejumlah error-nya, daya tariknya, kecocokannya dengan kebutuhan, dst,[1]. Evaluasi memiliki tiga tujuan utama [2], yaitu :

a) Melihat seberapa jauh sistem berfungsi, Mencakup kesesuaian penggunaan system terhadap harapan user pada tugas tersebut. Evaluasi pada tahap ini meliputi pengukuran unjuk kerja dari user pada system, untuk melihat keefektifan system dalam mendukung tugas.

b) Melihat efek interface bagi pengguna, Mencakup aspek dari kemudahan system dipelajari, daya guna dan perilaku user.

c) Mengidentifikasi masalah khusus yang terjadi pada system. Ketika penggunaan suatu konteks memberikan hasil yang tidak diinginkan, atau terjadi kekacauan di antara user. Tujuan ini merupakan aspek negatif dari desain.

\section{METODE PENELITIAN}

Metode penelitian yang digunakan adalah metode studi kasus [4]. Metode yang digunakan dalam review ini diawali dengan melakukan studi literatur tentang metode Interaksi Manusia dan Komputer dan metode Heuristic. Metode Heuristik ini banyak digunakan dalam mengukur tingkat kenyamanan pengguna.

Setelah melakukan studi literatur selanjutnya dilakukan penilaian terhadap aplikasi SOPPPOS berdasarkan prinsip Heuritic, aspek yang dinilai pada aplikasi SOPPPOS adalah dari segi desain antarmuka aplikasi, tahap selanjutnya yaitu menetapkan rekomendasi terhadap aplikasi yang telah dievaluasi menggunakan metode heuristik.

\subsection{Evaluasi Heuristik}

Evaluasi Heuristik adalah panduan, prinsip umum, atau aturan yang dapat menuntun keputusan rancangan atau digunakan untuk mengkritik suatu keputusan yang sudah diambil [3]. Evaluasi Heuristik diusulkan oleh Nielsen dan Molich, hampir sama dengan Cognitive Walkthrough tetapi sedikit terstruktur dan sedikit terarah. Pada pendekatan ini, sekumpulan kriteria usability atau heuristic diidentifikasi dan perancangan dilaksanakan misalnya dimana kriteria dilanggar.

Tujuan dari evaluasi heuristik adalah untuk memperbaiki perancangan secara efektif. Evaluator melakukan evaluasi melalui kinerja dari serangkaian tugas dengan perancangan dan dilihat kesesuaiannya dengan kriteria setiap tingkat. Jika ada kesalahan terdeteksi maka perancangan dapat ditinjau ulang untuk memperbaiki masalah ini sebelum tingkat implementasi. 
Evaluasi Heuristik sangat baik digunakan sebagai teknik evaluasi desain, karena lebih mudah untuk menemukan atau menentukan masalah usability yang muncul. Untuk menggunakan evaluasi ini dibutuhkan software yang akan diteliti atau storyboard untuk sistem yang akan dibuat [3].

\subsection{Aturan Evaluasi Heuristik}

Dalam melakukan evaluasi, terdapat sepuluh prinsip dalam Evaluasi Heuristik [5], yaitu:

1. Visibilitas dari status sistem (Visibility of system status (feedback)), Sistem harus selalu menginformasikan pada pengguna apa yang sedang terjadi, melalui pesan yang baik dan waktu yang sesuai.

2. Kesesuaian antara sistem dan dunia nyata (Match between system and the real world), Sistem harus berbicara sesuai dengan bahasa penggunanya, menggunakan kata, kalimat, dan konsep yang biasa digunakan oleh pengguna.

3. Kendali dan kebebasan pengguna (Use Control and Freedom), Pengguna harus dapat secara bebas memilih dan melakukan pekerjaan (sesuai kebutuhan). Pengguna harus dapat mengambil keputusannya sendiri (dengan informasi yang jelas) berkaitan dengan pekerjaan yang sedang/akan dilakukan. Sistem harus memiliki kemampuan untuk undo dan redo.

4. Standar dan konsistensi (Consistency and Standards), Pengguna tidak perlu mempertanyakan lagi mengenai perbedaan pemahaman pada sebuah kata dan kalimat, situasi dan aksi. Semua harus sudah mengikuti standar yang ada.

5. Pencegah kesalahan (Error Prevention), Merancang sistem yang mencegah terjadinya kesalahan lebih baik daripada merancang pesan kesalahan yang baik.

6. Bantu pengguna untuk mengenali, men-diagnosa, dan mengatasi masalah (Recognation Rather than Recall), Pengguna tidak perlu mempertanyakan lagi mengenai perbedaan pemahaman pada sebuah kata dan kalimat, situasi dan aksi. Semua harus sudah mengikuti standar yang ada.

7. Fleksibilitas dan efesiensi (Flexibility and Efficient of Use), Bagaimana membuat sebuah sistem yang mengakomodasi pengguna yang sudah ahli dan pengguna yang masih pemula. Berikan alternatif untuk pengguna yang "berbeda" dari pengguna biasa (secara fisik, budaya, bahasa, dll).

8. Estetika dan desain yang minimalis (Aesthetic and Minimalist Design), Sistem hanya menghasilkan informasi yang relevan, informasi yang tidak relevan mengurangi visibilitas dan usability dari sistem.

9. Pertolongan pengguna mengenal, berdialog dan memperbaiki kesalahan (Help users recognize, dialogue, and recovers from errors), Pembuatan objek, aksi dan pilihan harus jelas terlihat. Pengguna tidak harus mengingat-ingat informasi dari satu halaman ke halaman lain. Instruksi dan informasi pada sistem haras mudah diakses dan jelas terlihat pada saat dibutuhkan.

10. Fitur bantuan dan dokumentasi (Help and Documentation), Sistem harus memiliki dokumentasi yang relevan dan fitur help yang baik, sehingga pengguna dapat mempelajari segala sesuatu yang terkait dengan sistem.

\section{HASIL DAN PEMBAHASAN}

Sepuluh prinsip dalam evaluasi heuristik yang disebutkan di atas, kemudian dijadikan sebagai pedoman dalam mengevaluasi desain antar muka dari aplikasi front-end SOPPPOS. Hasil dan pembahasan dari evaluasi tersebut adalah sebagai berikut:

\subsection{Visibility of system status (feedback)}

Sebuah sistem seharusnya dapat memberikan informasi kepada pengguna terhadap apa yang sedang terjadi. Prinsip ini berkaitan langsung dengan beberapa pertanyaan seperti : "Dimana saya sekarang?" dan “Dimana jalan selanjutnya?". Pada tampilan awal SOPPPOS, seperti ditunjukkan oleh Gambar 1, terdapat tombol-tombol menu yang ditampilkan cukup besar sehingga mudah dibaca dan dimengerti. Hal yang sama juga diperoleh pada modul login, yang ditunjukkan oleh Gambar 2. Pada halaman Login, terdapat user id, password dan tombol Login, sehingga pengguna tau apa yang dilakukan. Namun pada setiap sub menu / menu Layanan, dimunculkan icon-icon menu seperti search, cetak ulang, EDC, dll yang terlihat pada Gambar 3 tidak disertai dengan label menu. Tetapi ketika disorot akan muncul deskripsi dari tombol-tombol tersebut.

\subsection{Match between system and the real world (metaphor)}

Sistem harus menggunakan bahasa yang dapat dimengerti oleh pengguna. Bahasa dan istilah yang terdapat pada aplikasi SOPPPOS cukup mudah dimengerti oleh pengguna awam, sehingga pengguna 
tidak menghadapi kesulitan dalam menggunakan aplikasi ini. Sebagai contoh pada setiap menu layanan, petugas akan memahami apa yang harus diinputkan. (Gambar 4)

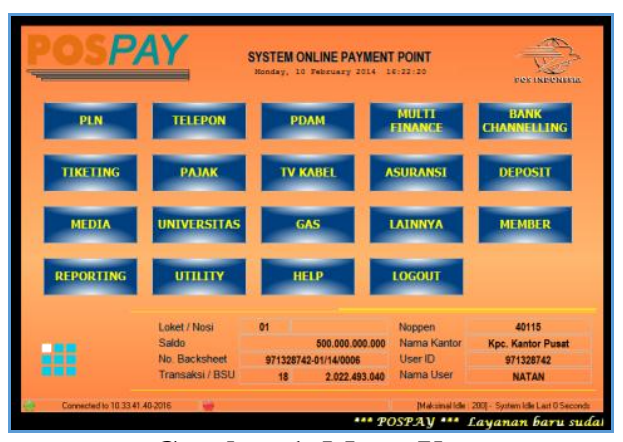

Gambar 1. Menu Utama

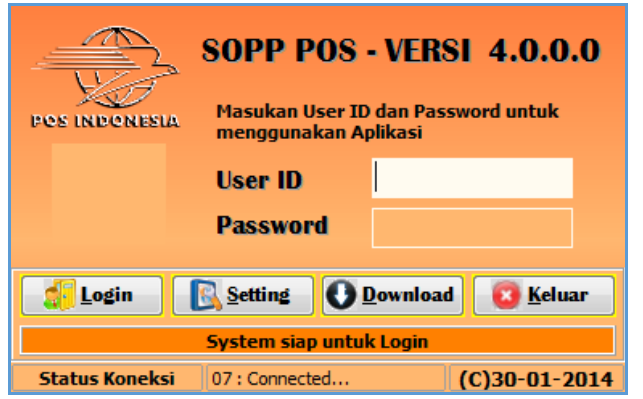

Gambar 2. Modul Login

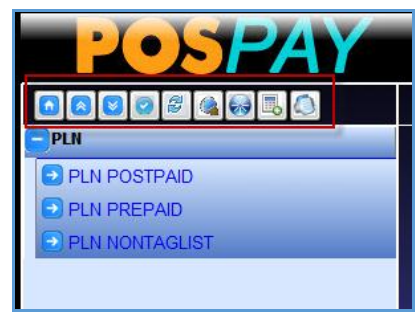

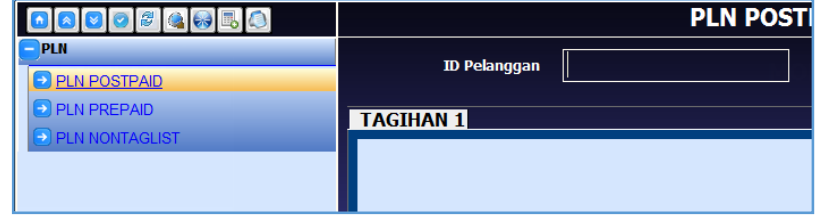

Gambar 4. Menu Entri Layanan PLN

Gambar 3. Menu Layanan PLN

\subsection{User control and freedom (navigation)}

Pengguna secara tidak sengaja sering memilih tautan menu yang tidak diinginkan. Oleh karena itu, dibutuhkan sebuah "pintu darurat" bagi pengguna untuk keluar dari tautan tersebut tanpa melalui langkah yang rumit. Seperti yang telah dijelaskan sebelumnya, setiap halaman layanan pada aplikasi SOPPPOS memiliki sebuah tombol menu yang terletak di atas sub menu layanan yang mengandung tautan ke Menu Utama yang akan memandu pengguna secara langsung. (Gambar 5)

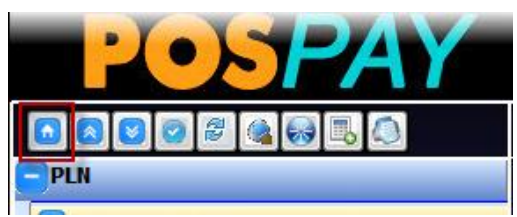

Gambar 5. Tombol dengan Icon Home

\subsection{Consistency and standards}

Sistem seharusnya tidak membuat bignung pengguna perihal apakah beberapa kata, situasi, dan prilaku yang berbeda dapat berarti hal yang sama. Aplikasi SOPPPOS memiliki konsistensi yang baik, setiap halaman memiliki desain, warna dan tema yang sama. Header dan menu juga selalu berada di lokasi yang sama. Hal ini berkaitan dengan standar aplikasi yang sederhana, tema yang minimalis dan tidak menggunakan tampilan grafis yang rumit.

\subsection{Error Prevention}

Pada aplikasi SOPPPOS banyak menggunakan inputan edit Text dan combobox. Untuk edit text disesuaikan dengan kebutuhan spesifikasi dengan mitra kerja, hal ini diantisipasi dengan tipe inputan yaitu Alphabet, Numerik, AlpaNumerik dan AlphaNumerik Symbol. Sehingga kesalahan input sudah di antisipasi apabila yang seharusnya input Numerik tetapi diisi Alphabet.

\subsection{Recognition rather than recall (memory)}

Pengguna tidak harus mengingat informasi dari satu bagian dialog ke bagian lainnya. Instruksi dari sistem seharusnya jelas dan dapat diprediksi dengan mudah. Aplikasi SOPPPOS sudah mengantisipasi hal ini, dengan menampilkan informasi disetiap proses dan setelahnya. 


\subsection{Flexibility and efficiency of use}

Aplikasi SOPPPOS ini dirancang sangat fleksibel dan effisien saat adanya penambahan menu / mitra baru. Hal ini cukup dengan melakukan sinkronisasi menu (Gambar 6.). Dengan begitu menghemat waktu, tenaga dan biaya jika ada penambahan menu.

\subsection{Aesthetic and minimalist design}

Sebuah dialog tidak boleh mengandung konten atau informasi yang tidak relevan dan tidak diperlukan. Setiap komponen harus mengandung arti dan fungsi yang sesuai dengan keperluan aplikasi tersebut. Aplikasi SOPPPOS diperuntukan bagi pelayanan public, sehingga desain yang ditampilkan haruslah sederhana tidak rumit yang bertele-tele. SOPPPOS telah memenuhi kriteria ini.

\subsection{Help users recognize, dialogue, and recovers from errors}

Pesan kesalahan harus ditampilkan berupa bahasa pengguna (bukan berupa kode), secara langsung mengidentifikasi masalah, dan memberikan solusi. Aplikasi SOPPPOS memenuhi kriteria ini, setiap informasi dimunculkan dalam bahasa yang mudah disamping di tampilkan respon code dan deskripsinya. Respon code untuk memudahkan saat melakukan konfirmasi trouble dengan bantuan HelpDesk dan Operational Support. (Gambar 7.)

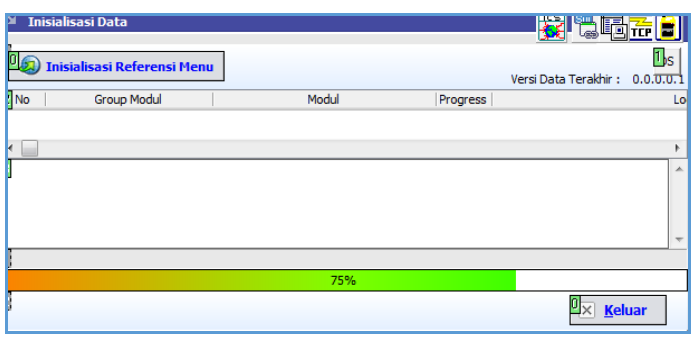

Gambar 6. Menu Sinkronisasi

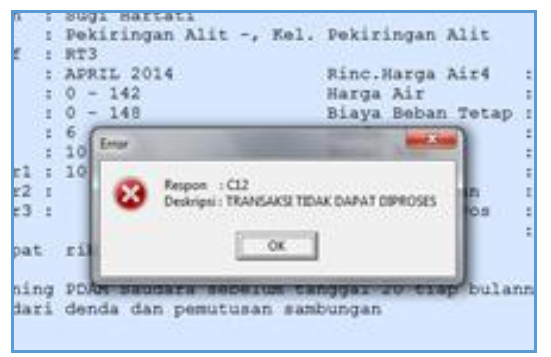

Gambar 7. Informasi Error

\subsection{Help and documentation}

Menu bantuan atau help sangat dibutuhkan pengguna sebagai pedoman untuk menggunakan sebuah aplikasi atau website. Sayangnya, aplikasi SOPPPOS tidak menyediakan mengisi menu help dengan Petunjuk Teknis dan Petunjuk Pelaksanaan yang pada prakteknya diedarkan terpisah secara hardcopy.

Rangkuman hasil evaluasi heuristik pada aplikasi SOPPPOS dapat dilihat pada Tabel 1 di bawah ini.

Tabel 1. Rangkuman Hasil Evaluasi

\begin{tabular}{|c|c|c|}
\hline No. & Deskripsi & Rekomendasi \\
\hline 1. & Visibility of system status (feddback) & $\begin{array}{l}\text { Perlu adanya peningkatan dalam evaluasi ini, diantaranya } \\
\text { notifikasi/feedback ketika user mengalami kendala }\end{array}$ \\
\hline 2. & $\begin{array}{l}\text { Match between system and the real } \\
\text { world (metapor) }\end{array}$ & $\begin{array}{l}\text { Perlu adanya penambahan icon/gambar yang merepresentasikan } \\
\text { menu-menu }\end{array}$ \\
\hline 3. & $\begin{array}{l}\text { User control and freedom } \\
\text { (navigation) }\end{array}$ & $\begin{array}{l}\text { Sudah ada tombol Tutup pada aplikasi. Dan semua tumbuh selalu } \\
\text { muncul saat berada di wilayah submenu (Tutup dan Ulang) }\end{array}$ \\
\hline 4. & Consistency and standards & $\begin{array}{l}\text { Perlu adanya konsistensi dalam bahasa yang digunakan, baik itu } \\
\text { bahasa Indonesia maupun bahasa Inggris }\end{array}$ \\
\hline 5 . & Error Prevention & $\begin{array}{l}\text { Perlu adanya suatu evaluasi yang khusus membahas tentang } \\
\text { pencegahan kesalahan ini. Salah satunya dengan desain yang } \\
\text { membedakan antara primary dan secondary action }\end{array}$ \\
\hline 6. & $\begin{array}{l}\text { Recognition rather than recall } \\
\text { (memory) }\end{array}$ & $\begin{array}{l}\text { Evaluasi ini perlu ditekankan kembali pada bagian lain dalam } \\
\text { aplikasi SOPPPOS }\end{array}$ \\
\hline 7. & Flexibility and efficiency of use & $\begin{array}{l}\text { Evaluasi ini perlu ditekankan kembali pada bagian lain dalam } \\
\text { aplikasi SOPPPOS }\end{array}$ \\
\hline 8. & Aesthetic and minimalist design & $\begin{array}{l}\text { Desain dan warna pada masing-masing menu dapat dibedakan } \\
\text { sedemikian rupa sehingga memudahkan dan menarik dalam } \\
\text { penggunaannya }\end{array}$ \\
\hline 9. & $\begin{array}{l}\text { Help users recognize, dialogue, and } \\
\text { recovers from errors }\end{array}$ & $\begin{array}{l}\text { Penambahan informasi mengenai cara ketika mengalami transaksi } \\
\text { Time Out, Cetak Resi sementara, dan resi tidak tercetak. }\end{array}$ \\
\hline 10. & Help and documentation & $\begin{array}{l}\text { Perlu adanya manual penggunaan yang uptodate dan informasi } \\
\text { penambahan mitra-mitra baru. }\end{array}$ \\
\hline
\end{tabular}




\section{KESIMPULAN DAN SARAN}

Dari hasil analisa dan pembahasan hasil dari penjelasan sebelumnya, dapat diambil kesimpulan sebagai berikut :

1) Evaluasi heuristik bersifat pragmatis, mudah dilakukan dan mendapatkan hasil yang cepat. Meskipun metode ini tidak menghasilkan solusi yang pasti, namun merupakan metode yang cukup mudah untuk memulai analisis terhadap desain sistem. Ekspektasi dari penelitian yang lebih lanjut adalah dengan menggunakan lebih dari satu metode untuk memperoleh hasil yang maksimal, karena tiap metode memiliki kelebihan dan kekurangan yang dapat dilengkapi oleh satu sama lain. Metode heuristik sendiri terdiri dari sepuluh prinsip yang berkaitan dengan berbagai aspek pada tampilan antarmuka dalam sebuah aplikasi. Pernilaian terhadap tiap kontek tekah dilakukan.

2) Secara umum desain antar muka (interface) pada aplikasi SOPPPOS sudah cukup baik berdasarkan evaluasi heuristik. Tetapi ada beberapa hal yang perlu ditingkatkan agar kemudahan usability (penggunaan) menjadi lebih baik lagi.

3) Karakteristik kemudahan usability berdasarkan evaluasi heuristik, ada beberapa poin yang perlu dikaji kembali seperti yang telah dibahas pada bagian pembahasan.

Beberapa hal yang dapat dijadikan sebagai masukan/saran adalah sebagai berikut:

1) Ada beberapa point sesuai hasil pembahasan yang perlu diperhatikan saat melakukan pengembangan lanjut, untuk memperhatikan aspek-aspek penggunaan. Saat update versi dapat di penuhi aspek-aspek tersebut.

2) Selain metode evaluasi heuristic dapat digunakan sebagai panduan dalam pengembangan aplikasi layanan dan bisnis lain dengan kemudahan penggunaan bagi petugas, pada prosesnya dapat dilengkapi dengan teknik-teknik lain sehingga didapat hasil evaluasi yang lebih baik.

\section{DAFTAR PUSTAKA}

[1] Preece Jennifer, Yvonne Rogers, Helen. Interaction Design Beyond Human-Computer Interaction. John Wiley \& Sons, Inc.; 2002. Chapter 1; What Is Interaction Design, page 6, 21-26. Chapter 6; The Process of Interaction Design; Page 169.

[2] Interaksi Manusia Dan Komputer, Materi IMK. [Internet] 2013 [diakses 10/12/2014] dari https://humcomint.wordpress.com/2013/11/23/evaluasi.

[3] Ridwan, A. Pengukuran Usability Aplikasi Menggunakan Evaluasi Heuristik. Jurnal Informasi Komputer vol 12. 2007. Hal. 218-228.

[4] Hasibuan, Zainal A. Metodologi Penelitian pada Bidang Ilmu Komputer dan Teknologi Informasi, Konsep, Teknik dan Aplikasi. Fakultas Ilmu Komputer Universitas Indonesia. 2007. Bab 4; Desain Penelitian; hal. 81.

[5] Nielsen, Jakob. M4 L4 Nielsen's Ten Heuristics, NPTEL - Computer Science and Engineering Human-Computer Interaction, ISSN 1548-5552. 2005. Page 1-6. 